\title{
Sphincter of Oddi function and dysfunction
}

\author{
James Toouli PhD FRACS, Alexander Craig FRACP
}

\begin{abstract}
J Toouli, A Craig. Sphincter of Oddi function and dysfunction. Can J Gastroenterol 2000:14(5):411-419. The sphincter of Oddi ( $\mathrm{SO})$ is situated at the junction of the bile and pancreatic ducts where they enter the duodenum, and it serves to regulate the flow of bile and pancreatic juices as well as to prevent the reflux of duodenal contents into the pancreatobiliary system. SO dysfunction relates to either the biliary or pancreatic portions of the sphincter. Distinct clinical syndromes relating to either sphincter segment are recognized. The mechanism of dysfunction remains uncertain, but disruption of neural pathways involved in sphincter function seems likely. SO dysfunction is best diagnosed by manometry, which is able to correctly stratify patient groups and determine therapy. Biliary scintigraphy, which is noninvasive, has shown promise as a screening tool for patients with suspected $\mathrm{SO}$ dysfunction. Division of the sphincter is an effective treatment for patients with manometrically proven $\mathrm{SO}$ stenosis for either the biliary or pancreatic form of the disorder. Other forms of SO dysfunction may benefit from pharmacotherapy.
\end{abstract}

Key Words: Biliary scintigraphy; Dyskinesia; Manometry; Sphincter of Oddi

\section{Fonction et dysfonction du sphincter d'Oddi}

RÉSUMÉ : Le sphincter d'Oddi (SO) est situé à la jonction des canaux biliaire et pancréatique à l'endroit où ils pénètrent dans le duodénum, et son rôle est de réguler le débit de la bile et des sucs pancréatiques ainsi que d'empêcher le reflux du contenu duodénal dans le système pancréatobiliaire. Une dysfonction du SO est attribuable soit à la partie pancréatique soit à la partie biliaire du sphincter. Des syndromes cliniques distincts se rapportant à l'un ou l'autre du segment touché sont reconnus. Le mécanisme de la dysfonction reste incertain mais serait probablement dû à une perturbation des voies nerveuses impliquées dans la fonction du sphincter. Une dysfonction du SO se diagnostique de préférence par manométrie qui peut stratifier correctement les groupes de patients et permettre d'établir un traitement. La scintigraphie biliaire, une technique non sanglante, est prometteuse comme outil de dépistage pour les patients chez qui on suspecte une dysfonction du SO. La division du sphincter est un traitement efficace chez les patients accusant une sténose du SO prouvée par manométrie, que le trouble soit d'origine pancréatique ou biliaire. D'autres formes de dysfonction du SO pourraient bénéficier d'une pharmacothérapie.
$\mathrm{N}$ early 400 hundred years ago, Frances Gliesson first described a sphincter structure at the distal end of the common bile duct where it enters the duodenum, but it was not until 1889, when Rugero Oddi described its anatomy and physiology in detail, that the function of this structure and its role in the control of flow of bile and pancreatic juices were appreciated. Oddi also postulated that patients would experience symptoms when this sphincter, which now bears his name, malfunctions. Since these initial observations, numerous studies have been conducted with the aim of understanding the way that the sphincter of Oddi (SO) functions and how its dysfunction produces a variety of clinical syndromes. As we enter into the 21 st century, our knowledge of the normal function of the sphincter has been considerably enhanced by these studies, and patients with dysfunctioning sphincters that produce symptoms can be identified. Furthermore, for a number of patients, therapies exist that produce good long term results. However, there are still large gaps in our understanding of the mechanism of dysfunction, and successful therapies for a significant number of individuals with SO dysfunction are lacking.

\section{SO FUNCTION}

The SO has been shown to be predominantly made up of circular and longitudinally orientated smooth muscle fibres that are embryologically distinct from the duodenum (1).

This mini-review was prepared from a presentation made at the 1998 World Congress of Gastroenterology, September 6 to 11, 1998, Vienna, Austria Gastrointestinal Surgical Unit, Department of Surgery, Flinders Medical Centre, Adelaide, South Australia

Correspondence: Professor James Toouli, Gastrointestinal Surgical Unit, Department of Surgery, Flinders Medical Centre, Bedford Park, Adelaide,

South Australia, 5042 Australia. Telephone 61-8-8204-5213, fax 61-8-8204-5966, e-mail Jim.Toouliflinders.edu.au

Received for publication May 3, 1999. Accepted May 10, 1999 


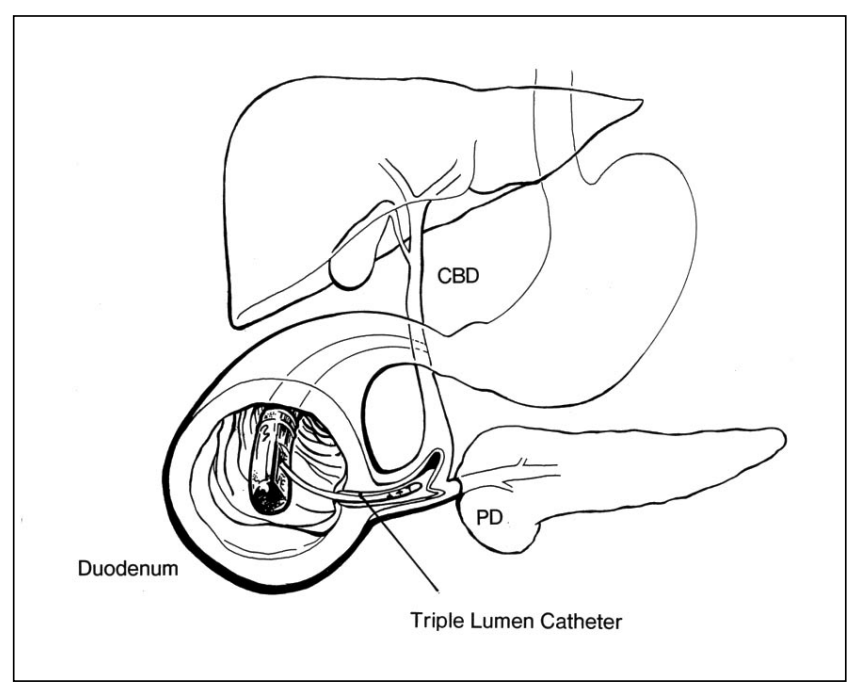

Figure 1) Endoscopic sphincter of Oddi manometry. The triple lumen catheter is passed through the biopsy channel of a duodenoscope and inserted into either the common bile duct (CBD) or pancreatic duct (PD) so that the three ports record from the sphincter. Reproduced with permission from reference 3

The muscular connections with the duodenum are thought to act as anchoring points and not to be functionally important. The $\mathrm{SO}$ shows similarities to duodenal activity in that its phase 3 activity of the migrating myoelectrical complex always precedes the duodenal phase 3 activity, but for the rest of the time the SO functions independently from the duodenum with regular phasic activity and no quiescent phase (2).

The function of the $\mathrm{SO}$ in humans has been characterized by manometric techniques that allow direct measurement of pressure changes using a small catheter directed into either the common bile duct or pancreatic duct (Figure 1). Intraluminal perfusion manometry has been able to characterize the human $\mathrm{SO}$ as having a modest basal tone with superimposed high pressure phasic waves (Figure 2) (3). The predominant function of the human $\mathrm{SO}$ appears to be to act as a resistor to the flow of bile and pancreatic secretions because most flow occurs between phasic waves (2). In humans, SO phasic waves may serve to keep the sphincter segment empty. There is considerable species variation. The $\mathrm{SO}$ in the American opossum has been show to act as a pump using cineradiography (4). This finding has drawn an analogy with the systolic and diastolic cycles of the heart, with flow occurring during systolic contraction and sphincter filling occurring during diastole. Tachycardia of the heart can lead to pump failure, and tachyoddia (high frequency SO phasic activity) can lead to a decrease in flow across the sphincter. The common factor across species with respect to $\mathrm{SO}$ function is that postprandially, flow across the sphincter is enhanced, regardless of whether the $\mathrm{SO}$ acts as a resistor or pump.

In humans, both postprandially (2) and following duodenal infusion of fats (5), SO tonic activity has been shown to be reduced. These SO changes that lead to the delivery of bile and pancreatic secretions into the duodenum are under

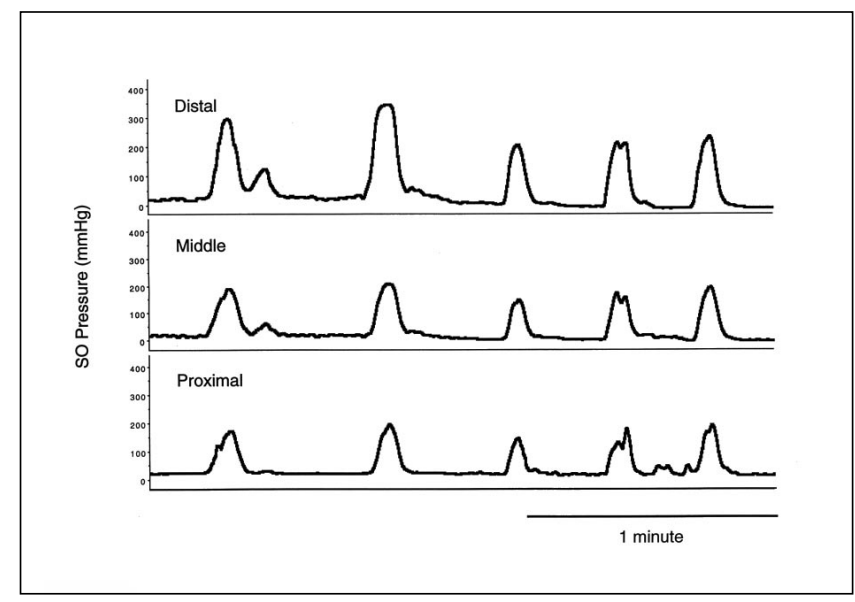

Figure 2) Normal sphincter of Oddi (SO) manometry

neurohormonal control. Neural connections of the SO to the duodenum and gallbladder have been identified using immunohistochemical techniques (6). Functional studies have demonstrated adrenergic, cholinergic and nonadrenergic noncholinergic (NANC) innervation. The adrenergic innervations are inhibitory and the cholinergic innervations are excitatory (7). NANC innervation appears to be inhibitory and mediated by nitric oxide (8). Local reflexes involving the $\mathrm{SO}$ have been demonstrated between the duodenum $(9,10)$, and gallbladder and bile ducts $(9,11-16)$. The predominant hormonal agent affecting $\mathrm{SO}$ motility is cholecystokinin (CCK). CCK is released by the duodenal mucosa into the circulation in response to duodenal luminal acid and nutrients, especially fats and amino acids (17). In humans, CCK has been shown to decrease the basal pressure and the amplitude of phasic waves of the SO (18). CCK release is inhibited by pancreatic enzymes (19) and bile salts (20) in the duodenum.

\section{SO DYSFUNCTION}

Clinical features: SO dysfunction has been known by many names in the past, including biliary dyskinesia, biliary spasm, biliary dyssynergia, papillary stenosis, papillitis, odditis and postcholecystectomy syndrome. There are two main clinical conditions that relate to what portion of the sphincter malfunctions. The more common problem is biliary SO dysfunction. Patients with dysfunction of the pancreatic portion of the sphincter usually include patients with idiopathic recurrent pancreatitis (21). Pancreatic pain without pancreatitis has also been suggested (22), but the definition of discrete pancreatic pain without clear pancreatitis is unclear.

Patients with biliary SO dysfunction are typically females (females to males seven to one) in their mid-40s and usually present five to seven years after having undergone cholecystectomy for cholelithiasis (23). Acute attacks can be associated with severe pain, as in patients with true biliary colic. However, apart from localized tenderness, signs of peritonism or fever are not present. The pain is situated in the epigastrium or right upper quadrant, often radiates into the back, and may be associated with nausea and vomiting. The 
TABLE 1

Sphincter of Oddi manometric pressures

\begin{tabular}{lrcc}
\hline & Normal & Median range & Abnormal \\
\hline Basal pressure $(\mathrm{mmHg})$ & 15 & $3-35$ & $>40$ \\
Amplitude $(\mathrm{mmHg})$ & 135 & $95-195$ & $>300$ \\
Frequency $(\mathrm{n} / \mathrm{min})$ & 4 & $2-6$ & $>7$ \\
Sequences & & & \\
$\quad$ Antegrade $(\%)$ & 80 & $12-100$ & \\
$\quad$ Simultaneous (\%) & 13 & $0-50$ & $>50$ \\
$\quad$ Retrograde (\%) & 9 & $0-50$ & Contracts \\
Cholecystokinin 20 ng/kg & Inhibits & & \\
\hline
\end{tabular}

pain generally occurs in episodes lasting up to several hours or until relieved by analgesics. Initial treatment of patients presenting with the above clinical symptoms is directed at relieving the pain, usually achieved by the administration of a systemic analgesic or buscopan. Pethidine (meperidine) is thought to be the most appropriate analgesic in patients with suspected SO dysfunction. These pain episodes may occur at intervals of weeks or months. Some patients also describe discomfort in the upper abdomen that is more frequent and may occur every day. The attacks of pain can occur after fatty meals and are often nocturnal. Patients may complain of sensitivity to codeine and other opiates, but this is nonspecific. Indeed, the first episode of pain may have been experienced following opiate medication, usually for an unrelated procedure. SO dysfunction is commonly associated with work absenteeism and health care use (24). One study (25) found that patients over-report nongastroenterological somatic complaints (ie, somatization disorder) and childhood sexual abuse, suggesting a role for broad psychiatric assessment and treatment of some patients with SO dysfunction.

The true extent of biliary SO dysfunction is difficult to know. In a study conducted over 30 years ago (26), 23.5\% of close to 2000 patients complained of mild biliary type pain two to nine years following cholecystectomy. In a more recent study (27), 6.4\% (29 of 454) of postcholecystectomy patients complained of biliary pain for which no other cause could be found. Fifteen of the 29 patients agreed to undergo SO manometry; two of the 15 patients (14\%) had abnormal manometry. Overall, the study suggested that after cholecystectomy, approximately $1 \%$ of patients will have SO dysfunction.

The pancreatic form of the disorder is seen in patients who have often been diagnosed with idiopathic recurrent pancreatitis in which no cause for the pancreatitis is apparent. These patients frequently have manometric abnormalities (28).

Whether patients with intact gallbladders have SO dysfunction is a matter of some debate. In a study of patients with intact gallbladders and idiopathic recurrent biliary type pain, SO manometry and gallbladder emptying studies were performed (29). Seventy per cent of these patients had an abnormal gallbladder ejection and/or SO manometry, but these abnormalities were independent of one another. In essence, this means that $\mathrm{SO}$ dysfunction can exist in the pres-
TABLE 2

Sphincter of Oddi dysfunction manometric criteria

\begin{tabular}{l} 
Stenosis \\
Basal pressure $>40 \mathrm{mmHg}$ \\
Dyskinesia \\
Frequency $>7 / \mathrm{min}$ \\
Intermittent rise in basal pressure \\
Retrograde contractions $>50 \%$ \\
Paradoxical cholecystokinin-octapeptide response \\
\hline
\end{tabular}

ence of an intact gallbladder, and gallbladder dyskinesia can occur with normal SO function. However, when assessing a patient with biliary type pain, the majority of clinicians act on an abnormal gallbladder ejection fraction by performing cholecystectomy and await the results of the surgery before considering investigating the SO.

Classification of SO dysfunction: Two classification systems for SO dysfunction have been developed for patients with biliary type pain. One system involves a 'clinical' classification based on endoscopic retrograde pancreatocholangiography (ERCP) and liver function test abnormalities (30) and the other, SO manometry (31).

The clinical classification system stratifies patients into three groups (types 1,2 and 3), depending on the likelihood that SO dysfunction is present. Type 1 patients have all three abnormalities: a dilated common bile duct $(12 \mathrm{~mm})$ on ERCP; delayed drainage of contrast for the common bile duct (45 mins); and, on two occasions in association with pain episodes, abnormal alkaline phosphatase (AP) or abnormal ratio of alanine aminotransferase to aspartate aminotransferase (twice the upper limit of normal) on liver function testing. Type 2 patients have one or two abnormalities, and type 3 patients experience pain with none of the above abnormalities. It is thought that $\mathrm{SO}$ dysfunction is present in all type 1 patients, approximately $50 \%$ to $60 \%$ of type 2 patients and fewer than $10 \%$ of type 3 patients. Type 3 patients are believed to be the patients most likely to have irritable bowel syndrome.

Manometry is able to describe patients as 'normal' or 'abnormal'. Normal manometric values have been determined from studies of healthy volunteers (Table 1 ), and abnormal values calculated as three standard deviations from the mean of normal values (Table 2). Patients with abnormal manometric values can be further classified into two subgroups of SO dysfunction. The first classification of abnormal manometry, $\mathrm{SO}$ stenosis, is represented by an elevated basal pressure $(40 \mathrm{mmHg})$. SO stenosis defines a manometric abnormality and not necessarily a fixed structural lesion. A good example of this is seen in patients with superimposed phasic activity on an elevated basal pressure diagnostic of $\mathrm{SO}$ stenosis. The other manometric abnormality is known as SO dyskinesia and broadly suggests an incoordinate sphincter. The manometric abnormalities include excessive retrograde propagation of phasic waves (50\%); an elevated basal pressure $(40 \mathrm{mmHg})$ that relaxes with CCK or other smooth muscle relaxants (eg, buscopan), which is often termed SO 
spasm; gigantic phasic wave amplitudes $(300 \mathrm{mmHg}$ above the baseline); high frequency of phasic waves (seven/min), which is often termed tachyoddia; and finally, a paradoxical response to CCK. A paradoxical response to CCK is defined as no change or an increase in phasic activity. $\mathrm{SO}$ spasm has also been used to describe patients with an intermittently raised basal pressure (32).

Both classification systems have strengths and weaknesses. Bile duct dilation following cholecystectomy has been suggested to be a common finding, but in a well conducted prospective study (33), bile duct dilation was usually found to be less than $1 \mathrm{~mm}$ five years after cholecystectomy. Delayed biliary drainage observed in one study (34) was found to be a common finding in asymptomatic subjects following cholecystectomy and, thus, not a specific abnormality in patients with suspected SO dysfunction. This study (34) has been methodolgically criticized for assessing biliary drainage in the prone position and for using a type of contrast that differed from that used in other studies (35). Assessment of contrast drainage at ERCP for up to $45 \mathrm{mins}$ is very labour intensive and rarely performed for the full 45 mins. The same criticism can be made about manometry; it probably uses even more resources and requires significant technical expertise to be undertaken. As well, manometry is invasive and carries the risk of pancreatitis (36).

With the clinical classification, type 2 patients are poorly delineated as normal or abnormal. The effects of endoscopic sphincterotomy have been studied in type 2 patients, and manometry performed before sphincterotomy (37). The only reliable predictor of response to the therapy, and presumably indicative of the correct diagnosis, was manometrically proven $\mathrm{SO}$ stenosis (ie, an elevated basal pressure). A further criticism of this system is that type 3 patients are not all normal. In one study (22), 28\% of type 3 patients were found to have manometrically proven SO stenosis. Another smaller study (38) found that $55 \%$ of type 3 patients had an elevated SO basal pressure. Response to sphincterotomy for type 3 patients, based on the manometric finding of an elevated basal pressure, has found differences in improvement compared with type 2 patients, and also the duration of improvement, suggesting that the clinical classification may provide additional information over manometry alone (39). One study (40) showed that type 1 patients appear to respond to sphincterotomy, even in the absence of manometric abnormalities, leading to the suggestion that manometry in type 1 patients may be misleading.

Overall, manometry is a more reliable system for correctly diagnosing and classifying patients. Manometry can also more often reliably predict response to therapy, accepting that the ERCP findings of a dilated duct and delayed drainage of contrast, as well as transient liver enzyme abnormalities, may provide additional information when deciding on an appropriate therapy.

A similar clinical classification system for pancreatic $\mathrm{SO}$ dysfunction has been proposed (22), but includes patients without pancreatitis and only 'pancreatic' pain. This condition of 'pancreatic' pain without pancreatitis is poorly defined. Manometry is clearly the superior way of classifying patients with pancreatic SO dysfunction.

Mechanism of SO dysfunction: The cause of SO dysfunction and the pain mechanism involved are uncertain. One potential mechanism is a neural defect leading to disturbed $\mathrm{SO}$ motility that may be due to a defect of the neural connections that coordinate the interaction between the duodenum, biliary tract and SO. In animals (11) and humans (41), the response to CCK is altered following cholecystectomy, suggesting that the surgery may in some way affect these neural connections. The neural pathways from the gallbladder and common bile duct to the $\mathrm{SO}$ are thought to have an inhibitory effect on the SO $(9,12)$. Interruption of these inhibitory neural pathways may lead to an increased tonicity of the $\mathrm{SO}$ with resistance to outflow in a biliary system that has lost its pressure reservoir, the gallbladder. In a small human study of patients with abdominal pain suspected to be $\mathrm{SO}$ dysfunction that was performed during endoscopic SO manometry, some patients after cholecystectomy did not show SO relaxation in response to artificial elevations of the common bile duct pressure by infusing saline (42). Normally, the SO should relax in response to elevations in the common bile duct pressure. It has also been shown that in the absence of the gallbladder, bile duct pressure is increased and the bile duct pressure increases in response to $\mathrm{SO}$ spasm induced by morphine, which was not seen with an intact gallbladder (43). There are reports of SO dysfunction following liver transplantation (44-46). After liver transplantation, the SO is essentially denervated. However, surgical interruption of neural pathways cannot be the only mechanism for SO dysfunction because patients with intact gallbladders have been shown to have manometrically proven SO dysfunction (29).

There is evidence that $\mathrm{SO}$ dysfunction may be part of a generalized motor disorder of the gastrointestinal tract. Small intestinal dysmotility has been seen in association with SO dysfunction (47-49). In one study (50), patients with irritable bowel syndrome and SO dysfunction demonstrated paradoxical responses to CCK more often than patients with $\mathrm{SO}$ dysfunction alone. A German publication (51) found abnormal esophageal and anorectal manometry in association with SO dysfunction.

A recent study (52) found duodenal hypersensitivity in patients with type $3 \mathrm{SO}$ dysfunction, suggesting that in these patients, abdominal pain may not originate exclusively in the biliary tree. Interestingly, there was no evidence of rectal hyperalgesia, which implied a site-specific process rather than a generalized visceral hyperalgesia.

Autonomic dysregulation has also been proposed as the cause of the motility disorder. Sympathetic overactivity has been found under basal conditions and during pain episodes in patients with postcholecystectomy pain who develop pain in association with morphine administration $(53,54)$. Furthermore, the severity of the pain in this patient group can be attenuated by clonidine (55), a sympathetic antagonist.

Secondary damage to the SO may result from the passage of small stones, or following inflammation of either the biliary tract or pancreas. This may result in repair by fibrosis. Fi- 
brosis of the $\mathrm{SO}$ has been seen in tissue acquired during surgery from patients with the diagnosis of papillitis (56). This may lead to a fixed structural stenosis, in keeping with the elevated basal pressure seen manometrically in patients with $\mathrm{SO}$ stenosis. However, some patients with an elevated basal pressure also show phasic activity, suggesting that, at least in these patients, a fixed structural lesion is unlikely.

Investigation of SO dysfunction: Blood screens during an acute attack of pain reveal a normal white cell count. About $10 \%$ to $20 \%$ of patients, however, show increases in serum concentrations of liver transaminases, particularly in blood specimens that are taken 3 to $4 \mathrm{~h}$ after the onset of pain. This is occasionally accompanied by increases in serum bilirubin and AP. In a subgroup of patients, serum amylase may be elevated either alone or in conjunction with changes in liver enzymes, and these patients are then considered to have the pancreatic form of the disorder.

Typical pain episodes of $\mathrm{SO}$ dysfunction are quite characteristic, but often other functional bowel disturbances can coexist, making diagnosis on history alone difficult. A trial of therapy for suspected irritable bowel syndrome can be considered where the history is vague, in the hope that this may improve symptoms and exclude $\mathrm{SO}$ dysfunction as a diagnostic possibility. Common bile duct stones need to be excluded in all patients with suspected SO dysfunction. The role of magnetic resonance cholangiopancreatography (MRCP) in evaluating the biliary tree in patients with a low likelihood of having common bile duct stones is unclear. At present, MRCP has not been shown to be superior than an ultrasound in detecting common bile duct stones (57). ERCP has the obvious advantage of being able to remove common bile duct stones at the time of the procedure and can also give an indication as to the possibility of $\mathrm{SO}$ dysfunction being present by an objective measurement of common bile duct diameter and whether contrast drains adequately. While these factors have not been shown to predict SO dysfunctions reliably, they can help in deciding whether to proceed to other investigations once common bile duct stones have been excluded. Pain on injection of contrast during ERCP has not been found to correlate with SO dysfunction (58). Biopsies from the papilla in a large series of patients with SO dysfunction found a $4.3 \%$ incidence of adenoma (59). If there is any suspicion that the papilla appears abnormal, biopsies should be considered.

The morphine-neostigmine test or Nardi test has been used in the past as a way to try and predict the response to sphincter division, either surgically or endoscopically. It is a very sensitive test (60), but lacks specificity (61) and has little role in the investigation of patients with suspected $\mathrm{SO}$ dysfunction.

Symptomatic improvement with common bile duct stenting has been shown to predict response to sphincterotomy (62). However, one study (63) showed a high rate of pancreatitis, and more studies are required before this approach can be recommended.

Biliary scintigraphy, which uses an imino acid that is taken up by hepatocytes and secreted unchanged into the biliary system while coupled to radioactive technitium, allows an assessment of bile flow. By being able to scan a region of interest over the biliary tree, time activity curves for bile flow can be generated. CCK is often administered to stimulate bile flow. Obstruction of the biliary tree has been shown to reduce bile flow, as assessed by scintigraphy (64). Many variables are used to assess obstruction, including the time taken to the maximal count over the biliary tree ( $\mathrm{T}$ max); the time taken for $50 \%$ of tracer to be seen over the biliary tree (half-life); the time taken for the tracer to enter the duodenum; prolonged excretion of tracer from the biliary tree; and the transit time of tracer from the hepatic hilum to the duodenum.

Although initial experience was generally favourable (65-71), there was variability in the parameters used for scintigraphy and diagnostic criteria for SO dysfunction. Sphincterotomy has been shown to improve bile flow, often to normal values (68-70). One study (72) assessed many scintigraphic variables and found that the hepatic hilum to duodenal transit time is the best predictor of delayed bile flow into the duodenum. This variable was then studied prospectively against $\mathrm{SO}$ manometry in patients with suspected $\mathrm{SO}$ dysfunction and found to have an $83 \%$ sensitivity and a $100 \%$ specificity (73). However, in patients with a dilated common bile duct, sphincterotomy was not found to normalize bile flow. A scoring system using six scintigraphic variables has been developed in an attempt to improve the accuracy of scintigraphy in patients with suspected $\mathrm{SO}$ dysfunction (74). In the 26 patients studied, $100 \%$ sensitivity and specificity of scintigraphy were found when compared with manometric criteria. These studies have not been repeated; thus, the results need to be confirmed before scintigraphy replaces manometry. A likely role for scintigraphy will be as a screening test, with manometry being used for equivocal results. Scintigraphy has not been found to be useful in diagnosing patients with suspected SO dysfunction and an intact gallbladder (75).

\section{SO MANOMETRY}

The development of techniques to measure pressure across the SO has enhanced our understanding of the normal physiology of the human $\mathrm{SO}$ and has also defined, with accuracy and reproducibility, the presence of manometric disorders of the sphincter (76). The miniaturized manometry catheters that are used for pressure measurement have three lumens and are made of either polyethylene or teflon. They have an outer diameter of $1.7 \mathrm{~mm}$. Three side holes are made at the recording tip of the catheter at $2 \mathrm{~mm}$ intervals, starting at $10 \mathrm{~mm}$ from its distal tip. Thus, the three lumens record across a length of $5 \mathrm{~mm}$ from within the SO. The catheter is connected to a pneumohydraulic capillary perfusion system with pressure force transducers in series. The catheter is perfused with deionized, bubble-free water at a flow rate of $0.13 \mathrm{~mL} / \mathrm{min}$ to $0.25 \mathrm{~mL} / \mathrm{min}$, and the whole system is capable of accurately recording pressure changes of up to $300 \mathrm{mmHg} / \mathrm{s}$. Mild sedation is usually achieved with intravenous benzodiazepine (diazepam or midazolam) or propo- 
TABLE 3

Endoscopic sphincterotomy (ES) and sphincter of Oddi (SO) dysfunction

\begin{tabular}{lcccc}
\hline & \multicolumn{2}{l}{$\begin{array}{l}\text { SO basal pressure } \\
<\mathbf{4 0} \mathbf{~ m m H g}\end{array}$} & SO basal pressure \\
& Sham & ES & Sham & ES \\
\hline $\mathrm{n}$ & 12 & 12 & 12 & 12 \\
Improve & $33 \%$ & $42 \%$ & $25 \%$ & $91 \%$ \\
No change & $67 \%$ & $58 \%$ & $75 \%$ & $9 \%$ \\
\hline
\end{tabular}

fol. These medications have been shown not to be associated with alterations in SO manometirc recordings (77-79). Before and during the manometric recording, drugs that alter sphincter motility, such as atropine and opiate analgesics, are avoided.

When the duodenoscope is in an appropriate position in relation to the papilla, the manometry catheter is inserted through the biopsy channel. The catheter is then passed into either the bile duct or pancreatic duct to record the duct pressure. It is then withdrawn so that all three recording ports are positioned within the sphincter segment (Figure 2). The response to an intravenous bolus dose of CCK-octapeptide $20 \mathrm{ng} / \mathrm{kg}$ is then assessed. Catheter position, either in the pancreatic duct or bile duct, may be assessed by injecting a small volume of contrast medium (less than $1 \mathrm{~mL}$ ) through the most distal port while briefly screening by fluoroscopy. Ideally, the catheter should record from the sphincter region of clinical interest (ie, biliary for biliary type pain, pancreatic for pancreatic pain) because discordant pressure recordings between the biliary and pancreatic portions of the sphincter have been reported (80-82). The overall risk of developing pancreatitis is $8 \%$ and is higher for patients with suspected pancreatic sphincter dysfunction than for suspected biliary sphincter dysfunction (36). Sacrificing one of the three recording channels to act as an aspiration port has been shown to reduce the incidence of pancreatitis in patients undergoing pancreatic sphincter manometry for suspected pancreatic sphincter dysfunction $(83,84)$. High perfusion flow rates have also been shown to increase the risk of pancreatitis (85).

Normal and abnormal manometric recordings have been identified in patients with clinically suspected SO dysfunction (Table 1). As discussed above, manometrically proven SO dysfunction has been subdivided into two major groups, irrespective of whether the symptoms are primarily biliary or pancreatic (Table 2) $(28,31)$. This manometric division of SO stenosis and SO dyskinesia has allowed targeting of specific therapy for patients in whom diagnosis of $\mathrm{SO}$ dysfunction is made.

\section{TREATMENT OF SO STENOSIS}

In a prospective study, patients with biliary-like pain were randomly assigned to endoscopic sphincterotomy or sham procedure (37). Manometry was done but was not used to determine therapy. The results of manometry were correlated with the clinical outcome (Table 3). After four years of follow-up, it was found that patients with SO stenosis treated by sphincterotomy were more likely to show improvement in symptoms than patients with sphincter stenosis who had the sham procedure. If the manometric diagnosis was $\mathrm{SO}$ dyskinesia, significant differences were not observed. The results from this study led to the conclusion that patients with significant SO dysfunction as characterized by an elevated basal pressure ( $\mathrm{SO}$ stenosis) should be treated by division of the SO. Similar results were reported around that time (86), and, subsequently, other prospective nonrandomized trials have confirmed the benefit of sphincterotomy for patients with an elevated basal pressure $(38,87,88)$. As discussed above, sphincterotomy for type 3 patients with an elevated basal pressure may not be associated with longlasting benefit (39).

In many patients with idiopathic recurrent pancreatitis, manometry reveals sphincter stenosis. Pancreatic duct stenosis may also be found in patients who have had a biliary sphincterotomy for the treatment of recurrent pancreatitis. Thus, endoscopic biliary sphincterotomy is often ineffective for recurrent pancreatitis, and treatment must include division of the pancreatic sphincter. This is achieved via a transduodenal approach at open operation with division of the septum between the bile duct and pancreatic duct, creating a wide opening for both ducts. Endoscopic division of the pancreatic portion of the $\mathrm{SO}$ has been reported but is not routinely undertaken because morbidity and long term outcome have not been evalutated. The results of total sphincter division in producing symptomatic relief in patients with recurrent pancreatitis depend on the selection of patients. Approximately $70 \%$ of patients with an abnormally elevated basal pressure are improved by sphincteroplasty and pancreatic septoplasty (89). Lack of improvement may relate to the fact that many of these patients have been treated for many years with a variety of analgesics, including opiates, and that some have developed dependance on medication.

\section{TREATMENT OF SO DYSKINESIA}

Sphincterotomy for patients with SO dyskinesia has been shown not to improve symptoms and cannot be recommended, especially in view of the increased risk of pancreatitis in patients with SO dysfunction $(90,91)$. The role of pharmacotherapy is somewhat unclear because there are few well conducted studies using manometric criteria for the diagnosis of SO dysfunction. The main drawback is that there are no drugs that appear to be specific for the $\mathrm{SO}$, are long acting and free of side effects. Nifedipine has been shown to reduce significantly $\mathrm{SO}$ basal pressure when given sublingually to patients with $\mathrm{SO}$ dyskinesia during $\mathrm{SO}$ manometry (92). Two studies have evaluated oral nifedipine for up to 12 weeks in patients with manometrically diagnosed 'SO spasm' (93) and suspected type $2 \mathrm{SO}$ dyskinesia (ie, no manometry) (94). Both studies found that, compared with placebo, there was a significant decrease in pain episodes and pain scores. The therapy was well tolerated, but concerns still exist regarding the potential for systemic side effects of hypotension, flushing and headaches. 
Glyceryl trinitrate given sublingually during $\mathrm{SO}$ manometry has been shown to decrease SO basal pressure in patients with suspected pancreatobiliary disease (95). However, no long term study has been undertaken using nitrates in patients with $\mathrm{SO}$ dysfunction.

Intrasphincteric injection of botulinum toxin has been shown in animals to relax the $\mathrm{SO}(96,97)$. It has also been used in an attempt to predict which patients may respond to further treatment, either by repeat injections of botulinim toxin or other therapy (98). The two patients who were treated showed an objective decrease in $\mathrm{SO}$ pressure for up to four months, but clinical improvement was not evident. Given the lack of clinical response, the need for repeat injections and concerns regarding the risks that the injection process may induce pancreatitis, intrasphincteric injection of botulinum toxin cannot be recommended for clinical use.

\section{REFERENCES}

1. Boyden EA. The anatomy of the choledochoduodenal junction in man. Surg Gynaecol Obstet 1957;104:641-52.

2. Worthley CS, Baker RA, Iannos J, Saccone GT, Toouli J. Human fasting and postprandial sphincter of Oddi motility. Br J Surg 1989;76:709-14.

3. Geenen JE, Hogan WJ, Dodds WJ, Stewart ET, Arndorfer RC. Intraluminal pressure recording from the human sphincter of Oddi. Gastroenterology 1980;78:317-24.

4. Toouli J, Dodds WJ, Honda R, et al. Motor function of the opossum sphincter of Oddi. J Clin Invest 1983;71:208-20.

5. Kalloo AN, Pasricha PJ. Effect of gastric distension and duodenal fat infusion on biliary sphincter of Oddi motility in healthy volunteers. Dig Dis Sci 1995;40:745-8.

6. Padbury RT, Furness JB, Baker RA, Toouli J, Messenger JP. Projections of nerve cells from the duodenum to the sphincter of Oddi and gallbladder of the Australian possum. Gastroenterology 1993;104:130-6.

7. Sarles JC, Awad R. Role of the autonomic nervous system in the rabbit sphincter of Oddi. Surg Gastroenterol 1984;3:41-6.

8. Baker RA, Saccone GT, Brookes SJ, Toouli J. Nitric oxide mediates nonadrenergic, noncholinergic neural relaxation in the Australian possum. Gastroenterology 1993;105:1746-53.

9. Wyatt AP. The relationship of the sphincter of Oddi to the stomach, duodenum and gall-bladder. J Physiol 1967;193:225-43.

10. Saccone GT, Harvey JR, Baker RA, Toouli J. Intramural neural pathways between the duodenum and sphincter of Oddi in the Australian brush-tailed possum in vivo. J Physiol 1994;481:447-56.

11. Grace PA, Pitt HA. Cholecystectomy alters the hormonal response of the sphincter of Oddi. Surgery 1987;102:186-94.

12. Thune A, Thornell E, Svanvik J. Reflex regulation of flow resistance in the feline sphincter of Oddi by hydrostatic pressure in the biliary tract. Gastroenterology 1986;91:1364-9.

13. Thune A, Saccone GT, Scicchitano JP, Toouli J. Distension of the gall bladder inhibits sphincter of Oddi motility in humans. Gut 1991;32:690-3.

14. Muller EL, Lewinski MA, Pitt HA. The cholecysto-sphincter of Oddi reflex. J Surg Res 1984;36:377-83.

15. Calabuig R, Weems WA, Moody FG. Choledochoduodenal flow: effect of the sphincter of Oddi in opossums and cats. Gastroenterology 1990;99:1641-6.

16. Shafik A. Cholecysto-sphincter inhibitory reflex: identification of a reflex and its role in bile flow in a canine model. J Invest Surg 1998;11:199-205.

17. Grace PA, Poston GJ, Williamson RC. Biliary motility. Gut 1990;31:571-82.

18. Toouli J, Hogan WJ, Geenen JE, Dodds WJ, Arndorfer RC. Action of cholecystokinin-octapeptide on sphincter of Oddi basal pressure and phasic wave activity in humans. Surgery 1982;92:497-503.

19. Owyang C, May D, Louie DS. Trypsin suppression of pancreatic

\section{SUMMARY}

It has taken over 100 years to provide the data to support Rugero Oddi's original observations on the function and dysfunction of the $\mathrm{SO}$. With our increased understanding of its normal physiology, we hope that it will not take as long to understand the mechanisms that control its motility and then malfunction to produce $\mathrm{SO}$ dysfunction. SO manometry remains the 'gold standard' for correctly diagnosing and stratifying treatment for patients with $\mathrm{SO}$ dysfunction. Biliary scintigraphy shows promise as a noninvasive screening investigation for patients with suspected $\mathrm{SO}$ dysfunction. For patients with $\mathrm{SO}$ stenosis, sphincterotomy is the treatment of choice. For patients with $\mathrm{SO}$ dyskinesia, pharmacotherapy may prove helpful in some patients, but systemic side effects may limit their use. Further studies into pharmacotherapeutic agents and botulinum toxin are needed.

enzyme secretion. Differential effect on cholecystokinin release and the enteropancreatic reflex. Gastroenterology 1986;91:637-43.

20. Gomez G, Lluis F, Guo YS, Greeley GH Jr, Townsend CM Jr, Thompson JC. Bile inhibits release of cholecystokinin and neurotensin. Surgery 1986;100:363-8.

21. Chen JWC, Saccone GTP, Toouli J. Sphincter of Oddi dysfunction and acute pancreatitis. Gut 1998;43:305-8.

22. Sherman S, Troiano FP, Hawes RH, O'Connor KW, Lehman GA. Frequency of abnormal sphincter of Oddi manometry compared with the clinical suspicion of sphincter of Oddi dysfunction. Am J Gastroenterol 1991;86:586-90.

23. Toouli J. What is sphincter of Oddi dysfunction? Gut 1989;30:753-61.

24. Drossman DA, Li Z, Andruzzi E, et al. U.S. householder survey of functional gastrointestinal disorders. Prevalence, sociodemography, and health impact. Dig Dis Sci 1993;38:1569-80.

25. Abraham HD, Anderson C, Lee D. Somatization disorder in sphincter of Oddi dysfunction. Psychosom Med 1997;59:553-7.

26. Bodvall B, Overgaard B. Computer analysis of postcholecystectomy biliary tract symptoms. Surg Gynecol Obstet 1967;124:723-32.

27. Bar-Meir S, Halpern Z, Bardan E, Gilat T. Frequency of papillary dysfunction among cholecystectomized patients. Hepatology 1984:4:328-30.

28. Toouli J, Roberts-Thomson IC, Dent J, Lee J. Sphincter of Oddi motility disorders in patients with idiopathic recurrent pancreatitis. Br J Surg 1985;72:859-63.

29. Ruffolo TA, Sherman S, Lehman GA, Hawes RH. Gallbladder ejection fraction and its relationship to sphincter of Oddi dysfunction. Dig Dis Sci 1994;39:289-92.

30. Hogan WJ, Geenen JE. Biliary dyskinesia. Endoscopy 1988;1:179-83.

31. Toouli J, Roberts-Thomson IC, Dent J, Lee J. Manometric disorders in patients with suspected sphincter of Oddi dysfunction. Gastroenterology 1985;88:1243-50.

32. Toouli J. Sphincter of Oddi. The Gastroenterologist 1996;4:44-53.

33. Hunt DR, Scott AJ. Changes in bile duct diameter after cholecystectomy: a 5-year prospective study. Gastroenterology 1989;97:1485-8.

34. Elta G, Barnett J, Ellis J, Ackermann R, Wahl R. Delayed biliary drainage is common in asymtomatic post-cholecystectomy normals Gastrointest Endosc 1992;38:435-9.

35. Khusro Q, Lehman GA. Delayed biliary drainage: help or hype? Am J Gastroenterol 1993;88:962-3.

36. Scicchitano J, Saccone GT, Baker RA, Roberts-Thomson IC, Toouli J. How safe is endoscopic sphincter of Oddi manometry. J Gastroenterol Hepatol 1995;10:334-6.

37. Geenen JE, Hogan WJ, Dodds WJ, Toouli J, Venu RP. The efficacy of endoscopic sphincterotomy after cholecystectomy in patients with sphincter-of-Oddi dysfunction. N Engl J Med 1989;320:82-7.

38. Botoman VA, Kozarek RA, Novell LA, et al. Long-term outcome after endoscopic sphincterotomy in patients with biliary colic and 
suspected sphincter of Oddi dysfunction. Gastrointest Endosc $1994 ; 40: 165-70$

39. Wehrmann T, Wiemer K, Lembcke B, Caspary WF, Jung M. Do patients with sphincter of Oddi dysfunction benefit from endoscopic sphincterotomy? A 5-year prospective trial. Eur J Gastroenterol Hepatol 1996;8:251-6.

40. Rolny P, Geenen JE, Hogan WJ. Post-cholecystectomy patients with "objective signs" of partial bile outflow obstruction: clinical characteristics, sphincter of Oddi manometry findings, and results of therapy. Gastrointest Endosc 1993;39:778-81.

41. Luman W, Williams AJ, Pryde A, et al. Influence of cholecystectomy on sphincter of Oddi motility. Gut 1997;41:371-4.

42. Rolny P, Funch-Jensen P, Kruse A, Thommesen P. Effect of cholecystectomy on the relationship between hydrostatic common bile duct pressure and sphincter of Oddi motility. Endoscopy 1991;23:111-3.

43. Tanaka M, Ikeda S, Nakayama F. Change in bile duct pressure responses after cholecystectomy: loss of gallbladder as a pressure reservoir. Gastroenterology 1984;87:1154-9.

44. Clavien PA, Camargo CA Jr, Baillie J, Fitz JG. Sphincter of Oddi dysfunction after liver transplantation. Dig Dis Sci 1995;40:73-4. (Lett)

45. Douzdjian V, Abecassis MM, Johlin FC. Sphincter of Oddi dysfunction following liver transplantation. Screening by bedside manometry and definitive manometric evaluation. Dig Dis Sci 1994:39:253-6.

46. Richards RD, Yeaton P, Shaffer HA Jr, et al. Human sphincter of Oddi motility and cholecystokinin response following liver transplantation. Dig Dis Sci 1993;38:462-8.

47. Soffer EE, Johlin FC. Intestinal dysmotility in patients with sphincter of Oddi dysfunction. A reason for failed response to sphincterotomy. Dig Dis Sci 1994;39:1942-6.

48. Evans PR, Bak YT, Dowsett JF, Smith RC, Kellow JE. Small bowel dysmotility in patients with postcholecystectomy sphincter of Oddi dysfunction. Dig Dis Sci 1997;42:1507-12.

49. Koussayer T, Ducker TE, Clench MH, Mathias JR. Ampulla of Vater/duodenal wall spasm diagnosed by antroduodenal manometry. Dig Dis Sci 1995;40:1710-9.

50. Evans PR, Dowsett JF, Bak YT, Chan YK, Kellow JE. Abnormal sphincter of Oddi response to cholecystokinin in postcholecystectomy syndrome patients with irritable bowel syndrome. The irritable sphincter. Dig Dis Sci 1995;40:1149-56.

51. Wehrmann T, Wiemer K, Lembcke B. [Esophagus and anorectal motility in patients with dysfunction of Oddi's sphincter]. Z Gastroenterol 1996;34:483-9.

52. Desautels SG, Slivka A, Hutson WR, et al. Postcholecystectomy pain syndrome: pathophysiology of abdominal pain in sphincter of Oddi type 3. Gastroenterology 1999;116:900-5.

53. Roberts-Thomson IC, Jonsson JR, Frewin DB, Coates GC. Sympathetic activation: a mechanism for morphine induced pain and rises in liver enzymes after cholecystectomy? Gut 1990;31:217-21.

54. Roberts-Thomson IC, Jonsson JR, Pannall PR, Frewin DB. Morphine responders with unexplained pain after cholecystectomy may have sympathetic overactivity. Clin Auton Res 1991;1:59-62.

55. Roberts-Thomson IC, Jonsson JR, Frewin DB. Sympathetic suppression attenuates anomalous responses to morphine in unexplained pain after cholecystectomy. Clin Auton Res 1994;4:185-8.

56. Acosta JM, Nardi GL. Papillitis. Inflammatory disease of the ampulla of Vater. Arch Surg 1966;92:354-61.

57. Toouli J, Wright TA. Gallstones. Med J Aust 1998;169:166-71.

58. Schmalz MJ, Geenen JE, Hogan WJ, Dodds WJ, Venu RP, Johnson GK. Pain on common bile duct injection during ERCP: does it indicate sphincter of Oddi dysfunction? Gastrointest Endosc 1990;36:458-61.

59. Ponchon T, Aucia N, Mitchell R, Chavaillon A, Bory R, Hedelius F. Biopsies of the ampullary region in patients suspected to have sphincter of Oddi dysfunction. Gastrointest Endosc 1995;42:296-300.

60. Madura JA, McCammon RL, Paris JM, Jesseph JE. The Nardi test and biliary manometry in the diagnosis of pancreaticobiliary sphincter dysfunction. Surgery 1981;90:588-95.

61. Steinberg WM, Salvato RF, Toskes PP. The morphine-prostigmin provocative test - is it useful for making clinical decisions? Gastroenterology 1980;78:728-31.

62. Rolny P. Endoscopic bile duct stent placement as a predictor of outcome following endoscopic sphincterotomy in patients with suspected sphincter of Oddi dysfunction. Eur J Gastroenterol Hepatol 1997;9:467-71.

63. Goff JS. Common bile duct sphincter of Oddi stenting in patients with suspected sphincter dysfunction. Am J Gastroenterol 1995;90:586-9.

64. Watson A, Kalff V. Hepatobiliary imaging. Curr Opin Radiol 1991;3:851-8

65. Zeman RK, Burrell MI, Dobbins J, Jaffe MH, Choyke PL. Postcholecystectomy syndrome: evaluation using biliary scintigraphy and endoscopic retrograde cholangiopancreatography. Radiology 1985;156:787-92.

66. Shaffer EA, Hershfield NB, Logan K, Kloiber R. Cholescintigraphic detection of functional obstruction of the sphincter of Oddi. Effect of papillotomy. Gastroenterology 1986;90:728-33.

67. Roberts-Thomson IC, Toouli J, Blanchett W, Lichtenstein M, Andrews JT. Assessment of bile flow by radioscintigraphy in patients with biliary-type pain after cholecystectomy. Aust N Z J Med 1986;16:788-93

68. Grimon G, Buffet C, Andre L, Etienne JP, Desgrez A. Biliary pain in postcholecystectomy patients without biliary obstruction. A prospective radionuclide study. Dig Dis Sci 1991;36:317-20.

69. Fullarton GM, Allan A, Hilditch T, Murray WR. Quantitative 99mTc-DISIDA scanning and endoscopic biliary manometry in sphincter of Oddi dysfunction. Gut 1988;29:1397-401.

70. Farup PG, Tjora S. Sphincter of Oddi dysfunction. Dynamic cholescintigraphy and endoscopic retrograde cholangiopancreatography with papillotomy in diagnosis, treatment, and follow-up study. Scand J Gastroenterol 1989;24:956-60.

71. Darweesh RM, Dodds WJ, Hogan WJ, et al. Efficacy of quantitative hepatobiliary scintigraphy and fatty-meal sonography for evaluating patients with suspected partial common duct obstruction. Gastroenterology 1988;94:779-86.

72. Cicala M, Scopinaro F, Corazziari E, et al. Quantitative cholescintigraphy in the assessment of choledochoduodenal bile flow. Gastroenterology 1991;100:1106-13.

73. Corazziari E, Cicala M, Habib FI, et al. Hepatoduodenal bile transit in cholecystectomized subjects. Relationship with sphincter of Oddi function and diagnostic value. Dig Dis Sci 1994;39:1985-93.

74. Sostre S, Kalloo AN, Spiegler EJ, Camargo EE, Wagner HN Jr. A noninvasive test of sphincter of Oddi dysfunction in postcholecystectomy patients: the scintigraphic score. J Nucl Med 1992;33:1216-22.

75. Kalloo AN, Sostre S, Meyerrose GE, Pasricha PJ, Szabo Z. Gallbladder ejection fraction. Nondiagnostic for sphincter of Oddi dysfunction in patients with intact gallbladders. Clin Nucl Med 1994;19:713-9.

76. Thune A, Scicchitano J, Roberts-Thomson I, Toouli J. Reproducibility of endoscopic sphincter of Oddi manometry. Dig Dis Sci 1991;36:1401-5.

77. Cuer JC, Dapoigny M, Bommelaer G. The effect of midazolam on motility of the sphincter of Oddi in human subjects. Endoscopy 1993;25:384-6.

78. Goff JS. Effect of propofol on human sphincter of Oddi. Dig Dis Sci 1995;40:2364-7.

79. Nebel OT. Manometric evaluation of the papillar of Vater. Gastrointest Endosc 1975;21:126-8.

80. Chan YK, Evans PR, Dowsett JF, Kellow JE, Badcock CA. Discordance of pressure recordings from biliary and pancreatic duct segments in patients with suspected sphincter of Oddi dysfunction. Dig Dis Sci 1997;42:1501-6.

81. Raddawi HM, Geenen JE, Hogan WJ, Dodds WJ, Venu RP, Johnson GK. Pressure measurements from biliary and pancreatic segments of sphincter of Oddi. Comparison between patients with functional abdominal pain, biliary, or pancreatic disease. Dig Dis Sci 1991;36:71-4.

82. Rolny P, Arleback A, Funch-Jensen P, Kruse A, Jarnerot G. Clinical significance of manometric assessment of both pancreatic duct and bile duct sphincter in the same patient. Scand J Gastroenterol 1989;24:751-4.

83. Sherman S, Hawes RH, Troiano FP, Lehman GA. Pancreatitis following bile duct sphincter of Oddi manometry: utility of the aspirating catheter. Gastrointest Endosc 1992;38:347-50.

84. Sherman S, Troiano FP, Hawes RH, Lehman GA. Sphincter of Oddi manometry: decreased risk of clinical pancreatitis with use of a modified aspirating catheter. Gastrointest Endosc 1990;36:462-6.

85. Meshkinpour H, Kay L, Mollot M. The role of the flow rate of the 
pneumohydraulic system on post-sphincter of Oddi manometry pancreatitis. J Clin Gastroenterol 1992;14:236-9.

86. Neoptolemos JP, Bailey IS, Carr-Locke DL. Sphincter of Oddi dysfunction: results of treatment by endoscopic sphincterotomy. Br J Surg 1988;75:454-9.

87. Fullarton GM, Murray WR. Evaluation of endoscopic sphincterotomy in sphincter of Oddi dysfunction. Endoscopy 1992;24:199-202.

88. Bozkurt T, Orth KH, Butsch B, Lux G. Long-term clinical outcome of post-cholecystectomy patients with biliary-type pain: results of manometry, non-invasive techniques and endoscopic sphincterotomy. Eur J Gastroenterol Hepatol 1996;8:245-9.

89. Toouli J, Difrancesco V, Saccone G, Kollias J, Schloithe A, Shanks N. Division of the sphincter of Oddi for treatment of dysfunction associated with recurrent pancreatitis. Br J Surg 1996;83:1205-10.

90. Sherman S, Ruffolo TA, Hawes RH, Lehman GA. Complications of endoscopic sphincterotomy. A prospective series with emphasis on the increased risk associated with sphincter of Oddi dysfunction and nondilated bile ducts. Gastroenterology 1991;101:1068-75.

91. Chen YK, Foliente RL, Santoro MJ, Walter MH, Collen MJ. Endoscopic sphincterotomy-induced pancreatitis: increased risk associated with nondilated bile ducts and sphincter of Oddi dysfunction. Am J Gastroenterol 1994;89:327-33.
92. Guelrud M, Mendoza S, Rossiter G, Ramirez L, Barkin J. Effect of nifedipine on sphincter of Oddi motor activity: studies in healthy volunteers and patients with biliary dyskinesia. Gastroenterology 1988;95:1050-5.

93. Khuroo MS, Zargar SA, Yattoo GN. Efficacy of nifedipine therapy in patients with sphincter of Oddi dysfunction: a prospective, double-blind, randomized, placebo-controlled, cross over trial. Br J Clin Pharmacol 1992;33:477-85.

94. Sand J, Nordback I, Koskinen M, Matikainen M, Lindholm TS. Nifedipine for suspected type 2 sphincter of Oddi dyskinesia. Am J Gastroenterol 1993;88:530-5.

95. Staritz M, Poralla T, Ewe K, Meyer zum Buschenfelde KH. Effect of glyceryl trinitrate on the sphincter of Oddi motility and baseline pressure. Gut 1985;26:194-7.

96. Wang HJ, Tanaka M, Konomi H, et al. Effect of local injection of botulinum toxin on sphincter of Oddi cyclic motility in dogs. Dig Dis Sci 1998:43:694-701.

97. Sand J, Nordback I, Arvola P, Porsti I, Kalloo A, Pasricha P. Effects of botulinum toxin $\mathrm{A}$ on the sphincter of Oddi: an in vivo and in vitro study. Gut 1998;42:507-10.

98. Pasricha PJ, Miskovsky EP, Kalloo AN. Intrasphincteric injection of botulinum toxin for suspected sphincter of Oddi dysfunction. Gut 1994;35:1319-21. 


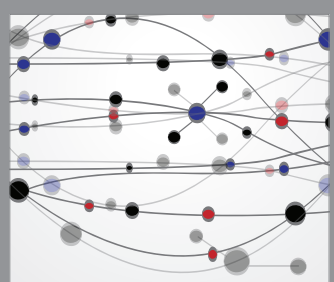

The Scientific World Journal
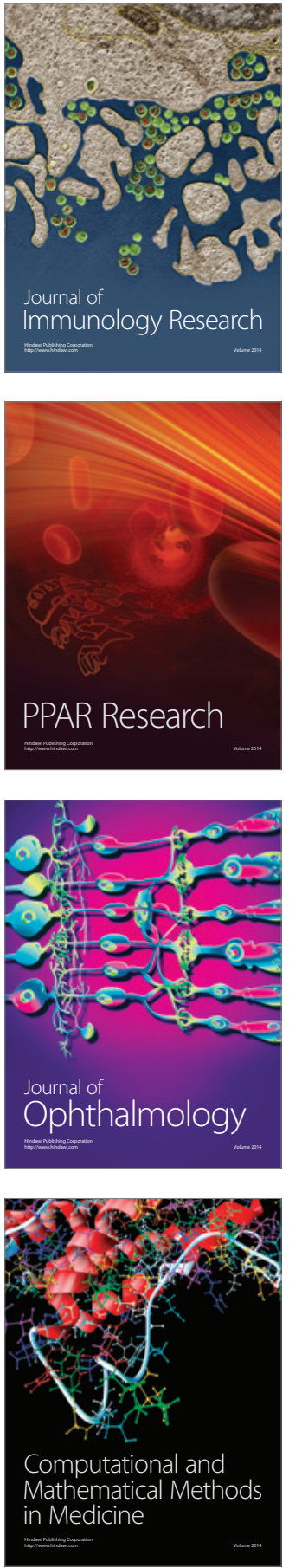

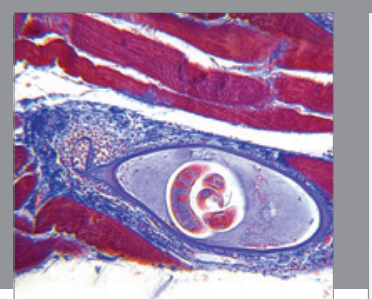

Gastroenterology Research and Practice

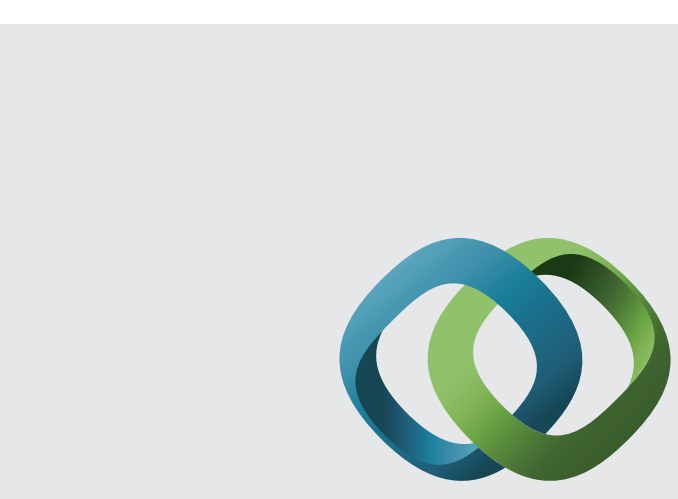

\section{Hindawi}

Submit your manuscripts at

http://www.hindawi.com
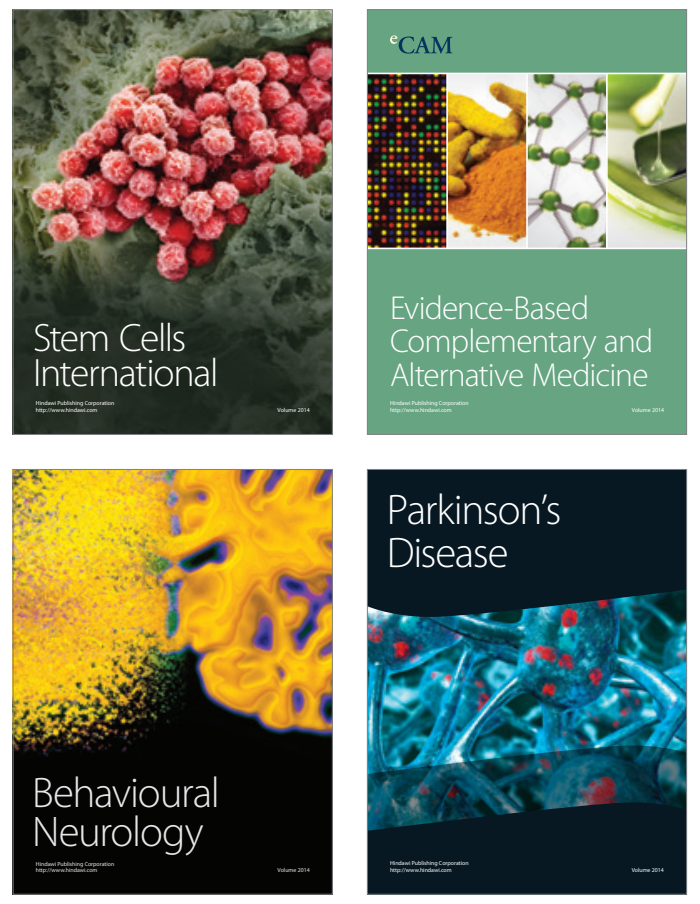
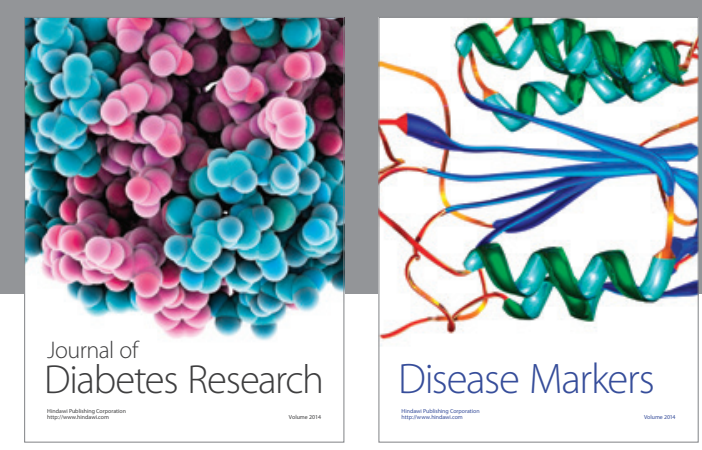

Disease Markers
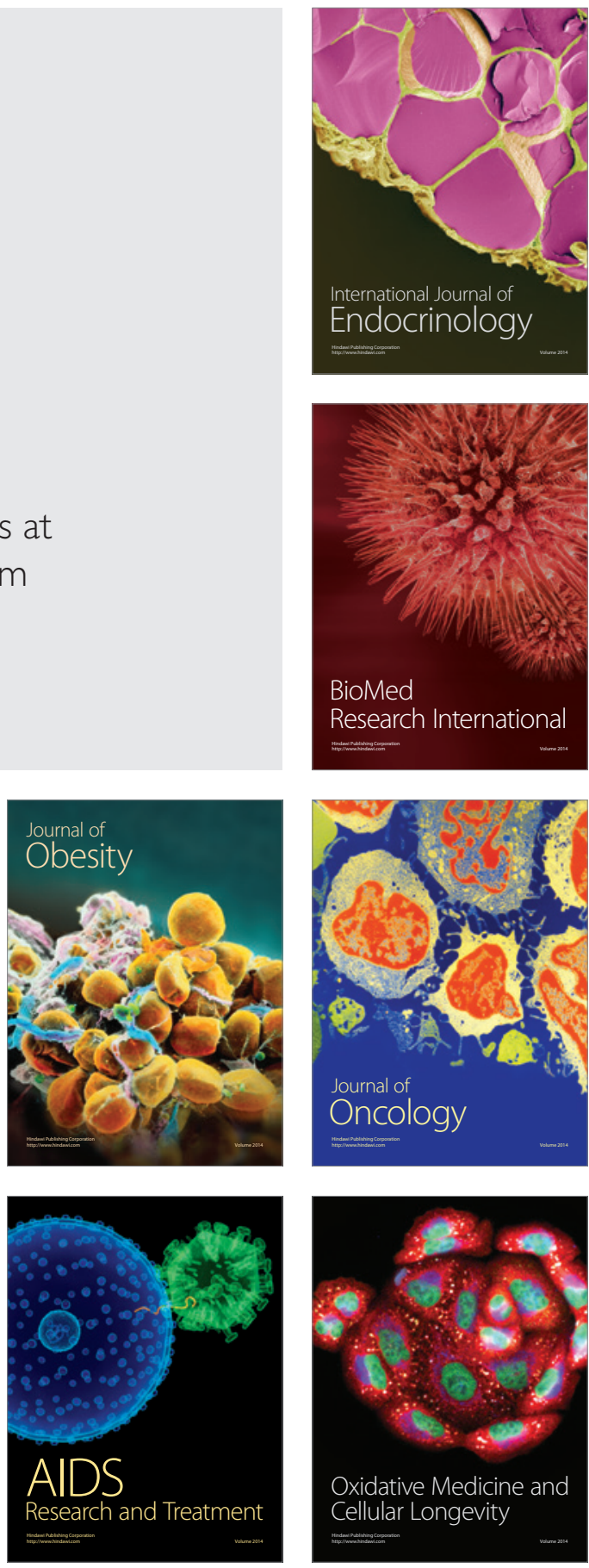